\title{
KESAKSIAN PEREMPUAN DALAM TRANSAKSI MUAMALAH MENURUT AL QURAN
}

\author{
Khairuddin \\ Program Pascasarjana UIN Suska Riau \\ kh4iruddin@yahoo.co.id
}

\begin{abstract}
In the al Quran explained that the testimony of two women equal to the testimony of a man. This was rejected by feminists because it felt unfair. This term is not for the weakness of the women sense, but because of that days, women lacked competence in the field of transaction of muamalah, therefore, her memory of that transaction was weak in that regard. If illat 'urfiy such as foundation, then his condition has changed, because in this era of globalization and the information women not only engaged in the domestic sector, but also in the public sector. In the economic field, women are no longer just a participant but instead have become a business person. Thus, the knowledge in the field of economics of courseno doubt anymore.
\end{abstract}

Kata Kunci: perempuan, saksi, transaksi muamalah

\section{PENDAHULUAN}

Masalah kesaksian merupakan persoalan penting dalam berbagai transaksi Islami. Kesaksian adalah terjemahan dari kata syahadah, mashdar dari syahida. Kata syahida dan yang seakar dengannya dalam al Quran terdapat 160 
kali diulang. ${ }^{1}$ Dari 160 ayat tersebut ada yang berkaitan dengan persoalan akidah, sifat Tuhan, kesaksian di hari kiamat dan persoalan kesaksian dalam hukum. Mengingat begitu banyak ayat al Quran yang berbicara tentang kesaksian, maka kajian ini dibatasi pada kesaksian perempuan dalam bidang transaksi muamalah.

Pada umumnya umat Islam berasumsi bahwa menurut al Quran, kesaksian perempuan hanya setengah kesaksian laki-laki. Karena itu dua saksi perempuan sama dengan satu orang saksi laki-laki. Asumsi ini kemudian menjadi keyakinan yang merupakan interpretasi terhadap al Quran (al Baqarah [2]: 282). Interpretasi ini telah diterima sejak berabad-abad yang lalu ketika kesadaran tentang hak-hak perempuan masih sangat minim. Mereka yang menolak memahami teks dalam konteksnya dengan kokoh meyakini bahwa perempuan dengan "desain" ketuhanan kurang cakap dibandingkan laki-laki. Karena itu kesaksiannya kurang bisa diandalkan dibanding laki-laki. Fenomena yang terjadi sekarang ini, kaum feminis menolak interpretasi tersebut karena dirasakan tidak adil, rasa tidak adil ini disebabkan kesadaran terhadap hak-hak perempuan makin meningkat, di mana perempuan "pada banyak kasus" bukan lagi "spesialis domestik", mereka telah merambah sektor publik dan bahkan tidak jarang mendominasi laki-laki. Realitas ini dirasakan setiap muslim di seluruh penjuru dunia. Selain kesadaran tentang hak-hak perempuan, penolakan ini juga didasarkan pada pemahaman terhadap teksteks keagamaan, terutama kitab-kitab tafsir al Quran yang kebanyakannya disusun di saat budaya patriarkhi masi h mendominasi. Pada sisi lain kita juga dihadapkan dengan al Quran sebagai tanzil al hakim yang diyakini sebagai kitab yang shalihun likulli waqtin wa zamanin. Ketika realitas hari ini berbeda dengan realitas ketika al Quran itu diinterpretasikan oleh banyak ulama, akankah kita mempertahankan hasil interpretasi yang telah ada, ataukah kita berupaya memberikan interpretasi lain berdasarkan konteks dan realitas hari ini ?

Beranjak dari realitas tersebut, kiranya perlu dilakukan "pembacaan ulang" (baca: penafsiran) teks-teks nash yang berbicara tentang kesaksian perempuan ini dengan mengajukan beberapa pertanyaan: Apa pengertian kesaksian, apa hukum kesaksian dalam Islam, bagaimana pernyataan Tuhan tentang kesaksian perempuan, agaimana interpretasi mufassir tentang kesaksian perempuan, apa dasar interpretasi mufassir sehingga sampai pada kesimpulan bahwa satu orang laki-laki sama dengan dua orang perempuan dalam hal memberikan kesaksian.

Pertanyaan-pertanyaan inilah yang perlu dijawab dengan melihat pada teks-teks nash yang berbicara tentang hal tersebut.

\section{PEMBAHASAN}




\section{A yat al Quran tentang Syahadah}

Ayat-ayat al Quran yang berbicara tentang kesaksian, terdapat pada

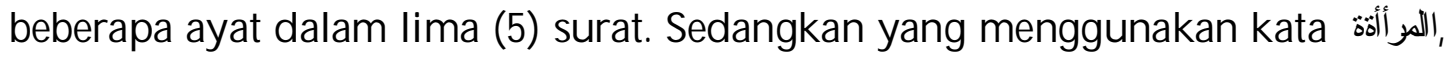
hanya terdapat pada satu ayat saja (al Baqarah [2]: 282), yaitu berbicara tentang transaksi muamalah. Mengingat persoalan transaksi selain muamalah juga dibutuhkan kesaksian, maka dalam kajian ini penulis mengemukakan ayat-ayat yang menuntut kesaksian tersebut, baik yang menyebutkan kata mar'ah maupun tidak. Apabila dilihat lebih lanjut berdasarkan kategori makiyah dan madaniyah², ayat-ayat tersebut semuanya adalah madaniyah, maka untuk menentukan urutannya penulis menggunakan kategori kronologis turunnya ayat al Quran berdasarkan riwayat A bdullah ibn Abbas. ${ }^{3}$

\section{Kesaksian Perempuan dalam Bidang M uamalah}

Kesaksian perempuan dalam bidang muamalah merujuk pada surat alBaqarah, ayat 282 dan 283 sebagai berikut:

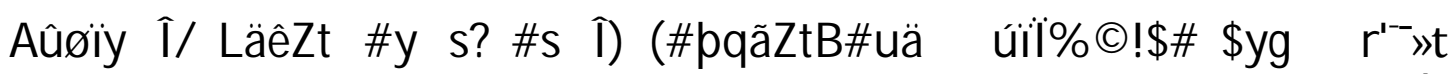

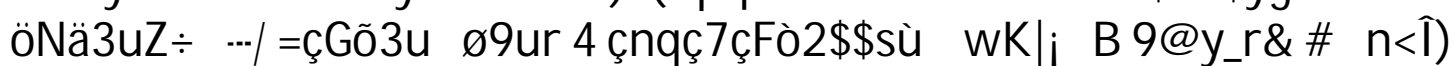

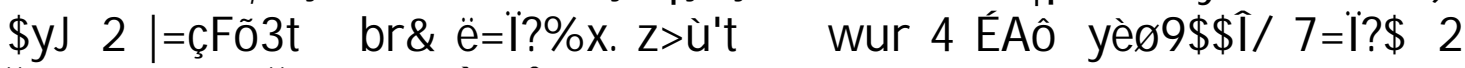

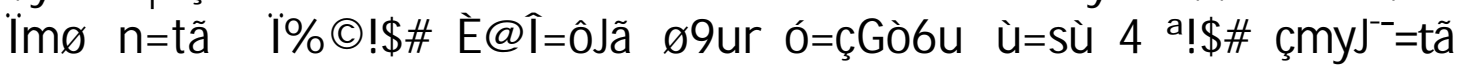
çm $\div$ Z̈̈B ó§y ö7t wur $1 / 4 \mathrm{Cm}---/ \mathrm{u}$. (c)!\$ E,-Gu ø9ur ,ysø9\$\#

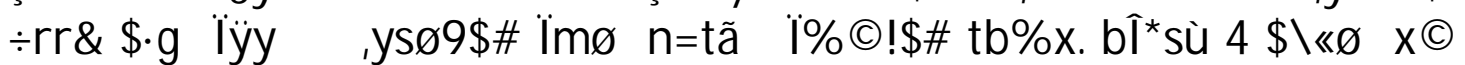
ö@ÎI=0̂Jã ù=sù uqèd “@ïJã br\& ßì ÏÜtGójo w

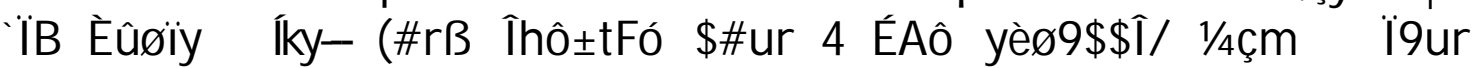

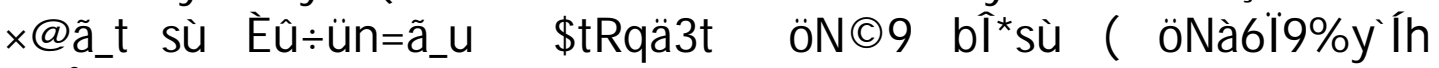

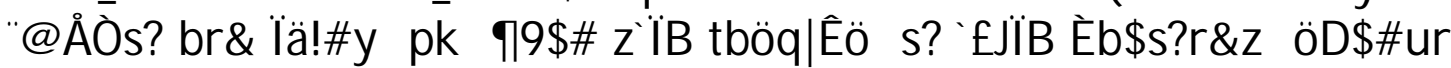
wur $43 \mathrm{t} \div \mathrm{zW}\{\$$ \# \$yJßg1y $\div \mathrm{n} \hat{\mathrm{I}})$ t Ae2x çFsù \$yJßg1y $\div \hat{\mathrm{I}}$ ) br\& (\#pqßJt«ójs? wur 4 (\#qããß \$tB \#s î) âä!\#y pk ॠ9\$\# z>ù't

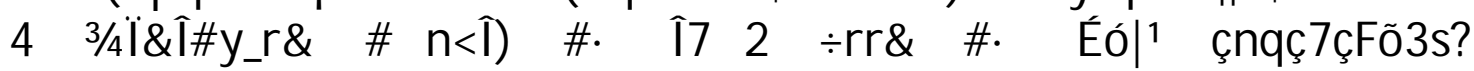
Íoy »pkøণ=̈̈9 ãPuqø\%r\&ur «!\$\# y ZÏ̃a äÝ|¡ø\%r\& öNä3Ï9ºs ot »yfï? cqä3s? br\& Hwî) ( (\#pqç/ \$s?ö s? wr\& \# oT $\div$ r\&ur ö/ä3ø n=tæ \}§ø n=sù öNà6oY $\div$ t/ \$ygtRrã $\ddot{I}$ è? Zou AÑ\%tn

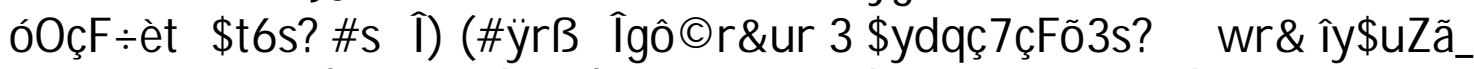

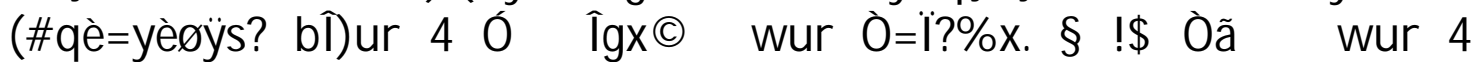

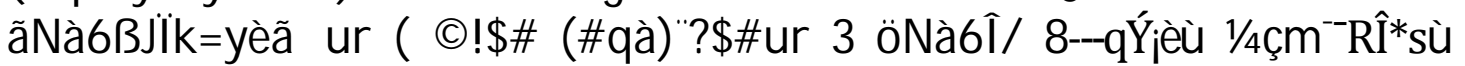

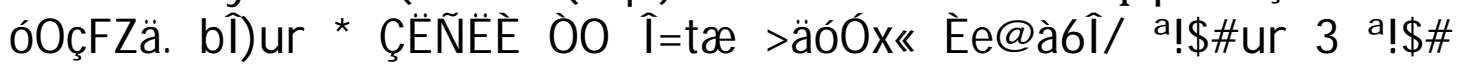

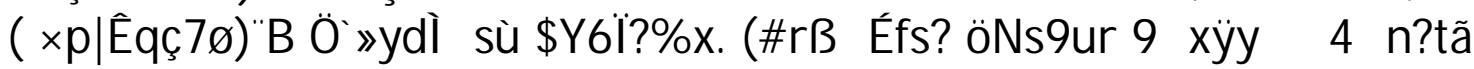

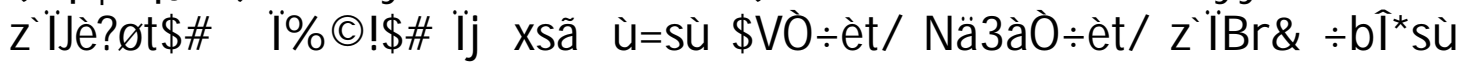
(\#qßJçGõ3s? wur 3 1/4Çm---/u C)!\$ Ë--Gu ø9ur 1/4ÇmtFuZ»tBr\& 
ÖNÏO\#uä $\ddot{y}^{1 / 4} 4 \mathrm{~cm}^{-2 R}{ }^{*}$ sù \$ygôJçGò6t ‘tBur 4 noy »ygx $\pm 9 \$ \#$ ÇẼÑ̇̀ ÒO Î=tæ tbqè=yJ Artinya: $\mathrm{H}$ ai orang-orang yang beriman, apabila kamu bermu amalah tidak secara tunai untuk waktu yang ditentukan, hendaklah kamu menuliskannya. $D$ an hendaklah seorang penulis di antara kamu menuliskannya dengan benar. Dan janganlah penulis enggan menuliskannya sebagaimana Allah telah mengajarkannya, maka hendaklah ia menulis, dan hendaklah orang yang berhutang itu mengimlakkan (apa yang akan ditulis itu), dan hendaklah ia bertakwa kepada Allah Tuhannya, dan janganlah ia mengurangi sedikitpun daripada hutangnya. Jika yang berhutang itu orang yang lemah akalnya atau lemah (keadaannya) atau dia sendiri tidak mampu mengimlakkan, maka hendaklah walinya mengimlakkan dengan jujur. $D$ an persaksikanlah dengan dua orang saksi dari orang-orang lelaki diantaramu). Jika tak ada dua orang Ielaki, maka (boleh) seorang lelaki dan dua orang perempuan dari saksi-saksi yang kamu ridhai, supaya jika seorang lupa maka seorang lagi mengingatkannya. Janganlah saksi-saksi itu enggan (memberi keterangan) apabila mereka dipanggil; dan janganlah kamu jemu menulis hutang itu, baik kecil maupun besar sampai batas waktu membayarnya. Y ang demikian itu, lebih adil di sisi Allah dan lebih dapat menguatkan persaksian dan lebih dekat kepada tidak (menimbulkan) keraguanmu, (Tulislah mu'amalahmu itu), kecuali jika mu 'amalah itu perdagangan tunai yang kamu jalankan di antara kamu, maka tak ada dosa bagi kamu, (jika) kamu tidak menulisnya. Dan persaksikanlah apabila kamu berjual beli; dan janganlah penulis dan saksi saling sulitmenyulitkan. Jika kamu lakukan (yang demikian), maka sesungguhnya hal itu adalah suatu kefasikan pada dirimu. Dan bertakwalah kepada Allah; Allah mengajarmu; dan Allah M aha M engetahui segala sesuatu.* Jika kamu dalam perjalanan (dan bermu'amalah tidak secara tunai) sedang kamu tidak memperoleh seorang penulis, maka hendaklah ada barang tanggungan yang dipegang (oleh yang berpiutang). A kan tetapi jika sebagian kamu mempercayai sebagian yang lain, maka hendaklah yang dipercayai itu menunaikan amanatnya (hutangnya) dan hendaklah ia bertakwa kepada Allah Tuhannya; dan janganlah kamu (para saksi) menyembunyikan persaksian. $D$ an barangsiapa yang menyembunyikannya, maka sesungguhnya ia adalah orang yang berdosa hatinya; dan Allah M aha M engetahui apa yang kamu kerjakan. (al-Baqarah: $282-283)$

\section{شها}

Kata syahida memiliki banyak makna, ketika kata syahida berubah menjadi syahiid yang merupakan salah satu nama bagi Allah SWT, ia mengandung arti dapat dipercaya kesaksiannya dan tidak satupun yang 
tersembunyi dari ilmunya. ${ }^{4}$ Syahiid juga berarti hadir. Kata ini juga mengandung arti pengetahuan dengan menggunakan istilah yang berbeda pada objek yang berbeda pula. Jika ditujukan pada masalah ilmu, digunakan istilah 'Aliim berarti mengetahui, jika dihadapkan dengan persoalan yang ghaib, digunakan istilah khabir, artinya juga mengetahui, jika yang menjadi objeknya adalah sesuatu yang zhahir (nyata) digunakan istilah syahiid artinya juga mengetahui. ${ }^{5}$

Berdasarkan pengertian kebahasaan di atas, dapat diketahui bahwa makna syahadah dapat dibagi dalam dua hal: pertama, kesaksian langsung, yaitu pengetahuan syahiid atas objek yang disaksikannya adalah pengetahuan langsung yang dihasilkan dengan cara melihat mendengar dan melihat. Dengan demikian, saksi adalah orang yang mengetahui sesuatu atau peristiwa dan membeberkan kesaksian tersebut pada orang lain, atau setidaknya ia siap dimintai kesaksian di hadapan mereka. Kedua, kesaksian tidak langsung, yakni kesaksian yang diperoleh dari kabar atau berbagai indikator yang ada.

Penggunaan kata syahida dalam al Quran, terkadang dalam arti kesaksian langsung dan terkadang dalam arti kesaksian tidak langsung dan terkadang dalam arti keduanya secara bersamaan (langsung dan tidak langsung). Kata syahida dalam arti kesaksian langsung dapat dilihat dalam al Quran (al Baqarah [2]: 282). Dalam hal ini saksi dituntut untuk menyaksikan transaksi yang sedang berlangsung dengan pendengaran dan penglihatannya, dengan demikian tidak sah kesaksian seorang yang buta dan tuli dalam transaksi muamalah. Selain itu seorang saksi juga disyaratkan supaya bersedia (tidak enggan) memberikan kesaksian ketika dibutuhkan sesuai dengan apa yang didengar dan dilihatnya.

Adapun penggunaan kata syahida dalam arti kesaksian tidak langsung adalah Firman Allah (al Baqarah [2]: 133):

ø Î) ßNöqyJø9\$\# z>qà) $\div$ èt u |Øym ø Î) uä!\#y pkà- öNçGYä. $\div \operatorname{Pr\& }$

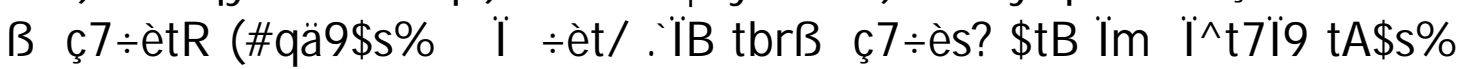

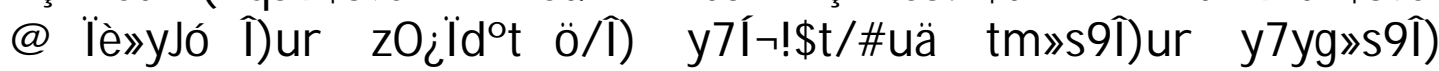

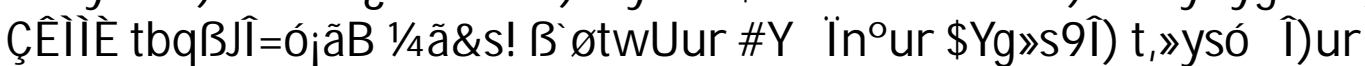
Artinya: A dakah kamu hadir ketika Ya’qub kedatangan (tanda-tanda) maut, ketika ia berkata kepada anak-anaknya: "Apa yang kamu sembah sepeninggalku?" M ereka menjawab: "Kami akan menyembah Tuhanmu dan Tuhan nenek moyangmu, Ibrahim, Ismail dan Ishaq, (yaitu) Tuhan Yang M aha Esa dan kami hanya tunduk patuh kepada-N ya. (al-Baqarah: 133)

Dalam ayat ini jelas bahwa umat yang membaca ayat ini dianggap sebagai saksi atas berlangsungnya wasiat nabi Ya'kub kepada anak-anaknya ketika telah datang tanda-tanda kematian, padahal kita tidak pernah 
mendapatkan pengetahuan tentang nabi Ya'kub kecuali melalui khabar, dalam ha ini adalah al Quran. Contoh lain adalah Firman Allah (Yusuf [ ]: 26 - 28): Yusuf berkata: "Dia menggodaku untuk menundukkan diriku (kepadanya)", dan seorang saksi dari keluarga wanita itu memberikan kesaksiannya: "Jika baju gamisnya koyak di muka, maka wanita itu benar dan Yusuf termasuk orang-orang yang dusta. $D$ an jika baju gamisnya koyak di belakang, maka wanita itulah yang dusta, dan Yusuf termasuk orang-orang yang benar." M aka tatkala suami wanita itu melihat baju gamis Y usuf koyak di belakang berkatalah dia: "Sesungguhnya (kejadian) itu adalah di antara tipu daya kamu, sesungguhnya tipu daya kamu adalah besar." Dalam hal ini kita dihadapkan dengan sebuah peristiwa yang terjadi di balik pintu yang terkunci, dalam sebuah kamar yang tidak ada seorangpun selain Yusuf dan istri al-Aziz dan tidak ada orang lain yang hadir sebagai saksi atas kejadian tersebut. Akan tetapi seorang saksi yang memberikan kesaksiannya, sesungguhnya memberikan kesaksian melalui petunjuk-petunjuk yang terdapat dalam informasi yang diberikan kepadanya, dari kronologis dan logika kejadian kemudian menyimpulkan. Lelaki yang menyergap perempuan untuk menganiaya akan mendekap dengan dadanya. Kalau si perempuan melakukan perlawanan, tentunya bekas perlawanan akan terlihat pada wajah, dada dan bagian depan pakaiannya. Adapun jika seorang perempuan berusaha mencegah laki-laki yang lari darinya dan berusaha menahannya, maka bekasnya akan terlihat pada punggung dan bagian belakang pakaiannya. Berdasarkan petunjuk-petunjuk yang ada diperoleh kesimpulannya bahwa isteri al-Aziz bersalah dan Yusuf benar.

Penggunaan kata syahida dalam arti kesaksian langsung dan tidak langsung secara bersamaan dapat dilihat dalam Firman Allah (al-Baqarah: 185): (Beberapa hari yang ditentukan itu ialah) bulan Ramadhan, bulan yang di dalamnya diturunkan (permulaan) AI Qur'an sebagai petunjuk bagi manusia dan penjelasanpenjelasan mengenai petunjuk itu dan pembeda (antara yang hak dan yang bathil). Karena itu, barangsiapa di antara kamu hadir (di negeri tempat tinggalnya) di bulan itu, maka hendaklah ia berpuasa pada bulan itu, dan barangsiapa sakit atau dalam perjalanan (lalu ia berbuka), maka (wajiblah baginya berpuasa), sebanyak hari yang ditinggalkannya itu, pada hari-hari yang lain. Allah menghendaki kemudahan bagimu, dan tidak menghendaki kesukaran bagimu. Dan hendaklah kamu mencukupkan bilangannya dan hendaklah kamu mengagungkan Allah atas petunjuk-N ya yang diberikan kepadamu, supaya kamu bersyukur. Melihat bulan di sini dipahami dalam dua bentuk, yakni melalui rukyah dan hisab. Dengan demikian, maka sangat disayangkan ketika ada upaya untuk menjustifikasi sebuah kebenaran mutlak kepada salah satu makna syahida dalam ayat ini.

\section{Hukum Kesaksian}


Ulama berbeda pendapat dalam menentukan hukum pencatatan dan kesaksian dalam transaksi muamalah. Menurut mazhab 'A tha', Ibn Juraij, Ibrahim al-Nakha'iy dan diikuti oleh Ibn Jarir al-Thabari, pencatatan dan kesaksian dalam transaksi muamalah hukumnya wajib. ${ }^{6} \mathrm{Hal}$ ini karena tidak ada yang dapat dipahami selain terwujudnya pencatatan dan kesaksian terhadap berlangsungnya transaksi muamalah (khususnya yang terdapat unsur hutang dan jangka waktu) sebagai mana dalam perintah-perintah lainnya dalam al Quran.

Menurut jumhur ulama fikih hukumnya sunat, mereka beralasan bahwa realitasnya di seluruh negera Islam dan muslim telah berlangsung transaksi jual beli dengan jangka waktu tertentu, namun tidak dilakukan pencatatan dan kesaksian, ini menunjukan bahwa berdasarkan kesepakatan (ijmak) kaum muslimin bahwa pencatatan dan kesaksian itu tidak wajib, selain itu juga jika diwajibkan sangat memberatkan bagi orang Islam. Ini juga diperkuat dengan

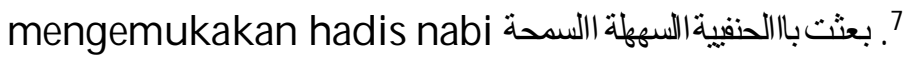

Menurut mazhab Hasan, al-Sya'bi, al-Hakam dan Ibn 'Uyainah, pencatatan dan kesaksian dalam transaksi muamalah pada awalnya wajib, kemudian hukumnya dinasakhkan oleh ayat (2: 283).

\section{Penalaran Ahli Tafsir}

I bn Katsir menjelaskan bahwa kesaksian perempuan setengah kesaksian laki-laki karena kurangnya akal perempuan. ${ }^{8}$ Dalam memberikan penjelasan ini ia menempuh tafsir bi al-ma'tsur, yakni dengan mengutip hadis yang diriwayatkan Muslim:

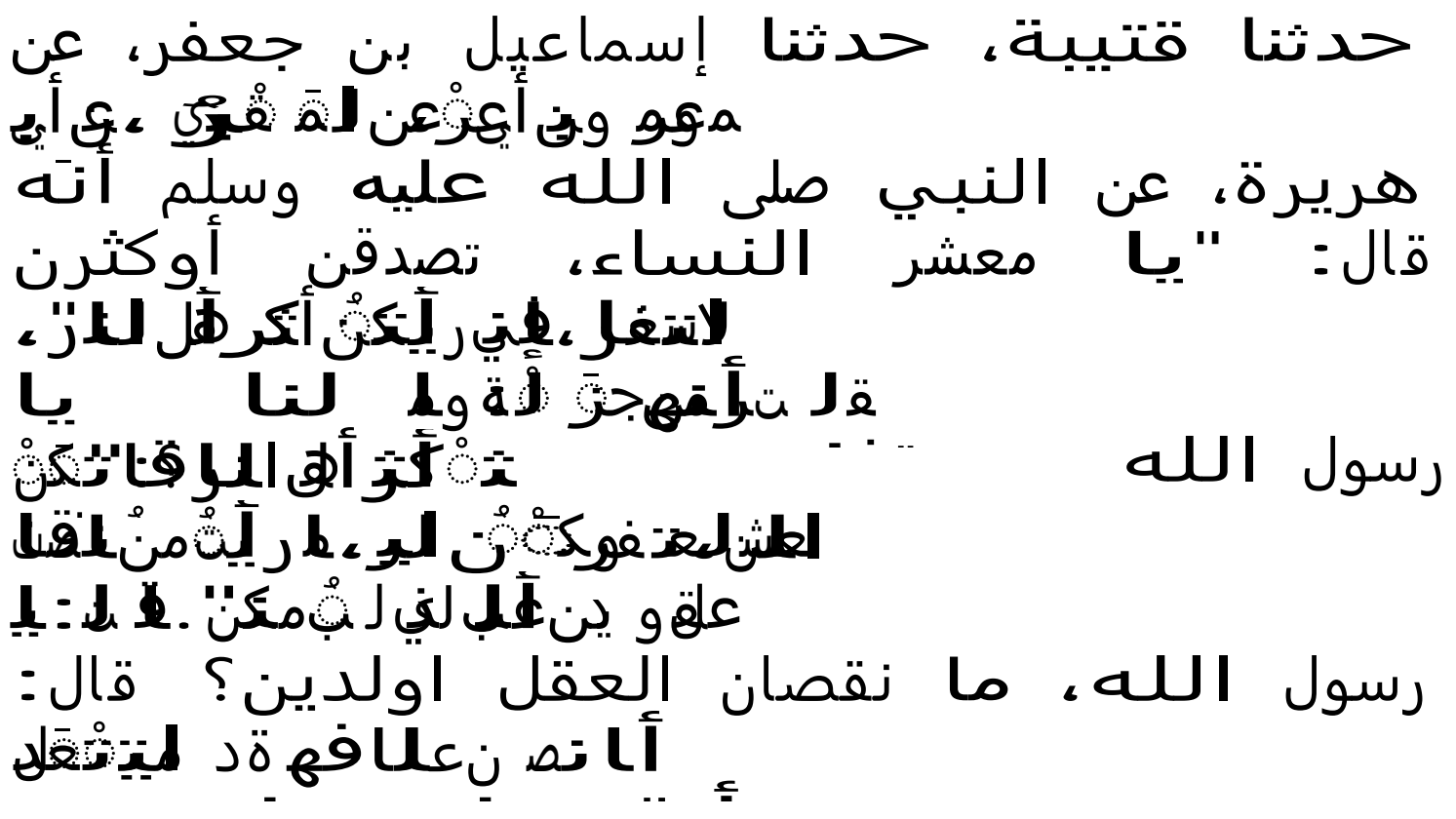




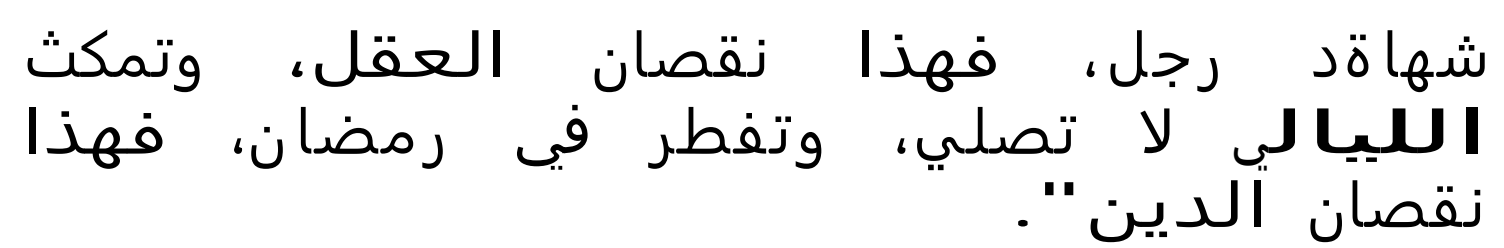

Ibn Katsir tidak memberikan penjelasan lebih lanjut tentang persoalan ini maupun hadis yang dikutip, ia memadakan pendapatnya dengan hadis tersebut.

Thabari memperluas makna tadaayantum kepada berbagai transaksi muamalah lainnya yang terdapat unsur hutang dan waktu tertentu yang ditentukan. Kesaksian perempuan tetap menempati setengah kesaksian lakilaki dalam transaksi muamalah supaya jika salah seorang perempuan tersebut lupa dapat mengingatkan yang lainnya, karena memang sudah maklum tentang kesaksian perempuan. ${ }^{9}$

Razi menyebutkan, maksud kalimat من ررجلكم dalam al-Baqarah: 282 adalah mengandung arti bahwa saksi itu adalah muslim, merdeka dan orang yang sengaja dipersiapkan menjadi saksi karena keadilannya. Karena itu terdapat perbedaan tentang kesaksian hamba sahaya dan non muslim. Menurut Syuraij, Ibn Sirin dan Ahmad, hamba sahaya boleh menjadi saksi, karena berdasarkan keumuman ayat tersebut dipahami demikian. Selain itu, kemampuan akal manusia, agamanya dan keadilannya hanya dapat terhalang oleh kebohongannya. Adapun akal, agama dan keadilan itu tidak ada perbedaan antara orang merdeka dengan hamba sahaya, apabila syarat kesaksian tersebut ada pada hamba sahaya, maka ada haknya untuk memberikan kesaksian. ${ }^{10}$ Menurut Syafi'i dan Abu Hanifah, kesaksian hamba sahaya tidak dapat diterima, mereka beralasan dengan firman Allah SWT لإي ó . ayat ini menunjukkan bahwa seorang saksi wajib menghadiri tempat di mana dilangsungkannya persaksian, sedangkan hamba sahaya tidak memiliki kebebasan untuk pergi ke mana saja, karena itu berdasarkan ijmak (kesepakatan), hamba sahaya tidak wajib menghadiri persaksian tersebut. Karena itu ulama mensyaratkan kesaksian dapat diterima apabila saksi memiliki sifat-sifat sebagai berikut: merdeka, baligh, muslim, adil, punya pengetahuan tentang objek yang disaksikan, tidak ada kepentingan pribadi dari kesaksiannya, tidak ada tujuan menghilangkan mudharat dari dirinya, bukan orang yang biasa berbuat kesalahan, bukan orang yang rusak maruah-nya, tidak ada permusuhan antara saksi dengan orang yang melakukan transaksi.

Adapun tentang kesaksian perempuan setengah kesaksian laki-laki adalah karena tabiat kebiasaan perempuan lebih banyak bard (dingin) dan rathubah (basah dan lembab). Karena itu secara psikologis akan membuat mereka banyak lupa dan Ialai, jika kesaksian perempuan tersebut dua orang secara logika mereka akan terhindar dari kelalaian tersebut, karena kalau salah 
seorang di antara mereka lalai atau lupa, maka yang lainnya dapat mengingatkan, sehingga kedudukan dua orang saksi perempuan tersebut sebanding dengan satu orang laki-laki. ${ }^{11}$

Sayyid Quthub menjelaskan bahwa pada dasarnya kesaksian dalam transaksi muamalah adalah dua orang saksi laki-laki yang adil dan disukai masyarakat, lalu Allah SWT memberikan kemudahan dengan diperbolehkannya perempuan menjadi saksi. Dalam ayat ini ketentuan kesaksian ditujukan kepada laki-laki, karena memang merekalah yang senantiasa melakukan transaksi ini dalam masyarakat muslim, di mana seorang perempuan tidak dituntut untuk melakukan aktivitas-aktivitas ekonomi untuk menghidupi dirinya apalagi keluarganya. Karena itu perempuan sangat jarang sekali melakukan transaksi-transaksi di bidang ekonomi dan ini pula yang menyebabkan sedikitnya pengetahuan perempuan tentang transaksi muamalah, jika mereka menjadi saksi dikhawatirkan akan lupa atau Ialai karena sedikitnya pengetahuan mereka dan jarang melakukan transaksi tersebut. Jika salah seorang di antara mereka lupa, maka yang lainnya mengingatkan. Inilah hikmah mengapa kesaksian perempuan dalam transaksi muamalah ini setengan kesaksian laki-laki. ${ }^{12}$

Menurut Jassas, hukum 'azimah tentang saksi itu adalah dua orang lakilaki, tapi jika dua orang laki-laki tidak ada, maka berpindah ke hukum rukhshah yaitu boleh dengan satu orang laki-laki dan dua orang perempuan. Jassas memahami ini berdasarkan pemahaman terhadap tekstual ayat “...

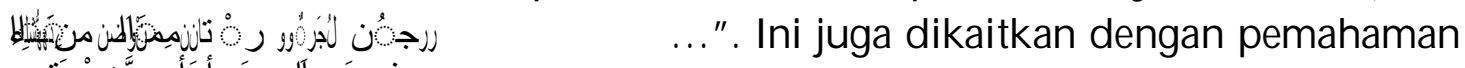
ayât läin séperti "kébolehan menggunakan tanah pada tayammum untuk bersudi

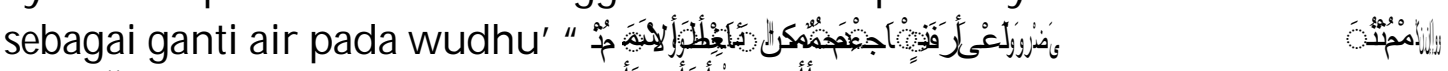

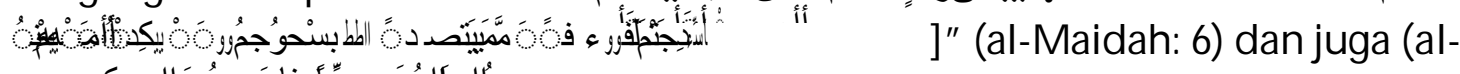
Nisa': 43). 'Dengân demikian, maka penyebutan dua orang saksi itu adalah dua orang laki-laki atau satu orang laki-laki dengan dua orang perempuan. ${ }^{13}$

Menurut Qurtubi, kesaksian dua orang perempuan tetap harus bersama dengan seorang laki-laki, karena berdasarkan kaedah kebahasaan bahwa kata

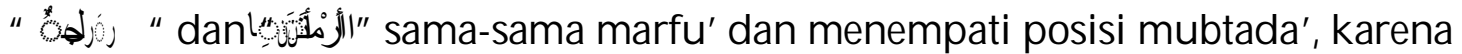
itu hukum yang melekat pada keduanya juga sama. ${ }^{14}$ Artinya, Qurtubi memahami bahwa yang dimaksud dalam ayat ini adalah kesaksian dua orang perempuan itu tetap harus digandeng dengan satu orang laki-laki.

Menurut Ibn 'Arabi, kesaksian perempuan setengah kesaksian laki-laki dalam persoalan hutang piutang dan transaksi muamalah lainnya karena Allah SWT mengutamakan laki-laki dari perempuan dalam enam bentuk: ${ }^{15}$ 1) Lakilaki adalah asal sedangkan perempuan adalah cabang, 2) Perempuan diciptakan dari tulang rusuk yang bengkok, 3) Kurang agamanya, Lemah akalnya, 4)Bahagiannya dalam warisan kurang, 5) Kurang tenaganya. 
Menurut Rasyid Ridha kesaksian perempuan setengah kesaksian lakilaki adalah karena dua alasan; pertama, kesaksian perempuan itu lemah, dan kedua, kurangnya kepercayaan orang banyak kepada perempuan. ${ }^{16}$ Lemahnya kesaksian perempuan ini disebabkan karena mereka tidak banyak andil dalam mengurusi persoalan harta. Rasyid Ridha menambahkan bahwa illat penetapan kesaksian dua orang perempuan sama dengan seorang laki-laki adalah kalimat

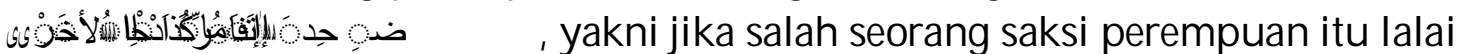
atau lüpä dâpat diingatkan oleh yang lainnya. ${ }^{17}$ Al-Khatib menambahkan lemahnya kesaksian perempuan itu disebabkan faktor fisik dan psikologis. ${ }^{18}$

Wahbah al-Zuhailiy mengakui bahwa illat penetapan hukum kesaksian perempuan setengah kesaksian laki-laki adalah al-tadzkir yang terdapat pada alBaqarah: 282, yakni di situ dipahami bahwa perempuan kurang dhabith dan suka lupa sehingga dapat diingatkan oleh saksi perempuan lainnya. Kurangnya pengetahuan ingatan perempuan bukan karena sifat kemanusiaannya, tetapi karena realitasnya mereka tidak banyak melakukan transaksi muamalah. Karena itu pengetahuannya terbatas dan sumber informasi yang diterima sedikit. Adapun sekarang, perempuan telah banyak andil dalam persoalan ekonomi, tetapi hal itu tidak dapat merobah hukum karena hukum berlaku untuk kebiasaan secara umum. ${ }^{19}$

Kebolehan dua orang perempuan bersama seorang laki-laki menjadi saksi pada semua transaksi selain hudud dan qisas. ${ }^{20}$ Sedangkan menurut Syafii hanya boleh dalam persalan harta saja. A hli fikih sepakat kesaksian dua orang perempuan bersama seorang laki-laki boleh dalam persoalan harta. Mereka berbeda pendapat pada persoalan selain harta; Menurut Sofyan al-Tsauriy dan ashab al-ra'y, boleh pada selain uqubat. Menurut Syafii kesaksian dua orang perempuan bersama seorang laki-laki atau empat orang perempuan boleh dalam persoalan kewanitaan sepert; willadah, penyusuan, keperawanan, pakayan dan lainnya, tetapi tidak boleh pada persoalan uqubah. ${ }^{21}$ Baghawi menambahkan bahwa syarat seorang saksi adalah; Islam, merdeka, berakal (waras), baligh, adil, terjaga muruahnya.22

Abu Hanifah, Abu Yusuf dan Muhammad: Kesaksian perempuan dengan laki-laki tidak diterima dalam masalah had dan qisas, tetapi diterima dalam masalah lain. ${ }^{23}$

\section{Analisa}

Sebelum menganalisa kedudukan kesaksian perempuan dalam al Quran, perlu ditinjau ulang tentang tujuan ditetapkannya hukum ${ }^{24}$ dan apakah ada illat tentang penetapan hukum dal am al Quran. Ketika membahas tentang qiyas, khususnya mengenai illat dalam kajian U shul al-Figh disebutkan bahwa illat

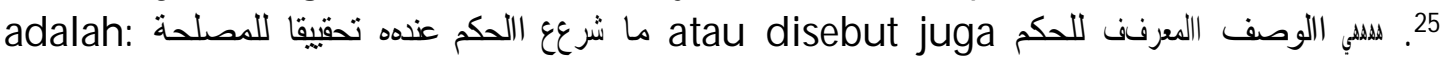


adapun tentang ada atau tidaknya illat dalam penetapan hukum, ahli U shul alFiqh mengemukakan kaidah yang sudah populer di kalangan ahli hukum,

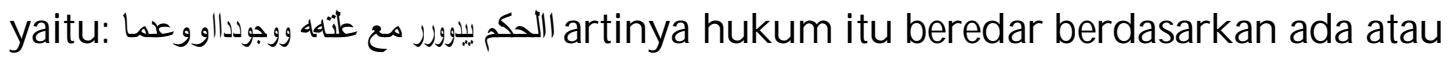

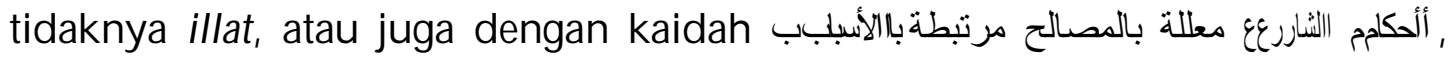
yakni hukum-hukum syar'i itu dihubungkan dengan kemaslahatankemaslahatan dan dikaitkan dengan sebab-sebab. ${ }^{26}$ Adapun illat yang terdapat dalam hukum tersebut ada yang 'aqliy, hissiy dan 'urfiy.

Dari penjelasan tentang ketentuan illat di atas dapat diketahui bahwa penetapan kesaksian perempuan dalam transaksi muamalah terdapat illat hukum. Namun persoalan berikutnya apakah illat hukum yang terdapat pada surat al-Baqarah ayat 282 tersebut 'aqliy, hissiy atau 'urfiy ?.

Mufassir sepakat bahwa illat hukum dalam penetapan kesaksian perempuan dalam transaksi muamalah pada surat al-Baqarah ayat 282 adalah

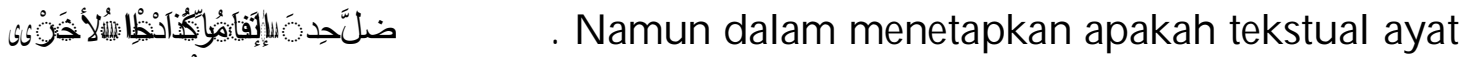
tersebứ y̌ang menjadi illat hukum atau makna yang terkandung di luar teks tersebut (baca: konteks) di mana dan kapan teks tersebut lahir.

Bagi mufassir yang menjadikan tekstualitas ayat tersebut sebagai illat hukum penetapan kesaksian perempuan dalam transaksi muamalah tidak ada pembahasan lebih lanjut, karena memang demikianlah ketentuan Allah SWT yang harus direspon dengan sami'naa wa 'atha'naa.

Bagi mayoritas mufassir, menerima tekstualitas ayat tersebut sebagai illat hukum, namun dalam penjelasannya mereka memberikan interpretasi lebih lanjut mengapa kesaksian perempuan setengah kesaksian laki-laki. Sayyid Quthub misalnya, menjelaskan bahwa kesaksian perempuan dalam transaksi muamalah setengah kesaksian laki-laki karena kurangnya pengetahuan perempuan dalam bidang ekonomi, sebab perempuan dal am budaya patriarkhi adalah konsumtif dan hanya diberikan ruang gerak pada sektor domestik.

Ada yang unik dan menarik pada penafsiran Sayyid Quthub. Pertama, ia mengakui bahwa penetapan kesaksian perempuan setengah kesaksian laki-laki karena ada illat. Kedua, ia mengakui realitas sebagai illat penetapan kesaksian perempuan. A pabila realitas masyarakat Arab dengan budaya patriarkhinya dijadikan dasar dalam meng-interpretasi-kan ayat tentang kesaksian perempuan, maka ketika itu tidak susah menerima ketentuan ini karena sesuai dengan konteks kebudayaan masyarakatnya. Namun jika dikaitkan dengan kebudayaan masyarakat hari ini di mana enam alasan yang dikemukakan oleh Ibn Arabi $^{27}$ untuk menunjukkan superioritas laki-laki atas perempuan, terutama poin kurang akal, agama dan tenaganya sulit diterima. Sebab di era globalisasi dan informasi ini perempuan bukan lagi spesialis sektor domestik, tetapi sudah merambah sektor publik dan dalam bidang ekonomi bukan lagi 
sekedar partisipan tetapi justru sudah menjadi pelaku bisnis. Dengan demikian maka pengetahuannya dalam bidang ekonomi tentu tidak diragukan.

Mahmud Syaltut menjelaskan bahwa kesaksian perempuan dalam transaksi muamalah, bukan menjelaskan tentang kesaksian yang akan dijadikan hakim sebagai dasar penetapan hukum, tetapi dalam bentuk irsyad supaya orang yang melakukan transaksi muamalah merasa lebih kuat dan aman terhadap hak-haknya ketika melakukan transaksi muamalah. Di sini bukan berarti kesaksian seorang perempuan atau kesaksian perempuan yang tidak disanding dengan laki-laki tidak dapat menetapkan hak atau dijadikan alasan dalam menetapkan hukum, karena yang paling dibutuhkan dalam hukum adalah pembuktian. Pengungkapan kekuatan kesaksian dua orang perempuan sama dengan seorang laki-laki bukan karena lemahnya akal perempuan yang dapat mengurangi eksistensi kemanusiaannya, tetapi karena perempuan kurang memiliki kompetensi di bidang transaksi muamalah karena itu ingatannya dalam hal tersebut lemah. Tidak demikian halnya dengan persoalan domestik yang digelutinya yang menjadikan ingatannya dalam hal tersebut lebih kuat dari laki-laki, dan sudah menjadi tabiat manusia bahwa ingatan mereka akan kuat tentang persoalan-persoalan yang banyak digelutinya. ${ }^{28}$

A pabila dianalisa lebih lanjut beberapa ayat yang menjelaskan tentang kesaksian, maka akan tergambar bentuk kesaksian dan hal yang paling esensial pada kesaksian sehingga kesaksian tersebut diterima dan atau ditolak (dicela). Allah SWT menyebutkan bahwa saksi bukanlah satu satunya bukti yang kuat dalam transaksi muamalah dan aspek hukum lainnya, akan tetapi dalam muamalah perlu dilakukan pencatatan yang benar, karena itu Allah berfirman "H ai orang-orang yang beriman, apabila kamu bermu'amalah tidak secara tunai untuk waktu yang ditentukan, hendaklah kamu menuliskannya. Dan hendaklah seorang penulis di antara kamu menuliskannya dengan benar (al-Baqarah: 282). dan apabila sulit mendapat orang yang akan mencatat transaksi tersebut dapat diganti dengan Jaminan yang harus dipegang oleh yang berpiutang, Jika kamu dalam perjalanan (dan bermu'amalah tidak secara tunai) sedang kamu tidak memperoleh seorang penulis, maka hendaklah ada barang tanggungan yang dipegang (oleh yang berpiutang) (al-Baqarah: 283), bahkan dalam sal ah satu kasus pidana Islam, li'an, ketika tidak ditemukan seorang saksipun kecuali dirinya sendiri, ia bersumpah empat kali atas nama Allah dapat menggantikan empat orang saksi, D an orangorang yang menuduh isterinya (berzina), padahal mereka tidak ada mempunyai saksisaksi selain diri mereka sendiri, maka persaksian orang itu ialah empat kali bersumpah dengan nama Allah, sesungguhnya dia adalah termasuk orang-orang yang benar (anNur: 6). 
Dari ayat-ayat di atas akan diketahui bahwa syahadah bukanlah satusatunya bukti dalam hukum, tetapi juga ditopang oleh bukti-bukti lain, sebagai berikut:

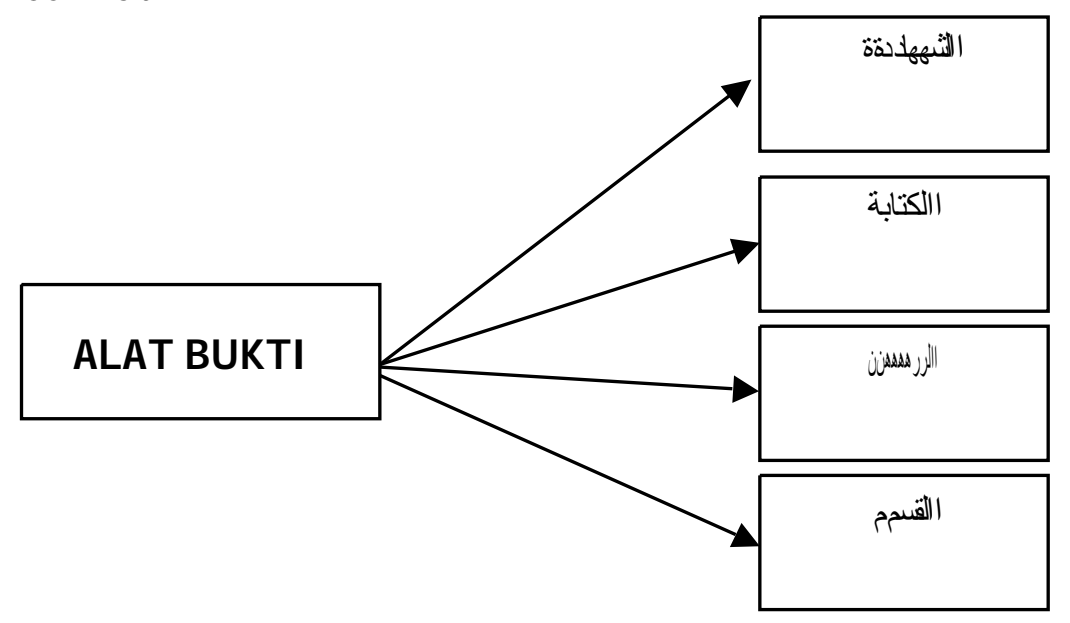

Adapun sifat-sifat yang melekat pada seorang saksi sehingga membuat kesaksiannya dapat diterima adalah; seorang saksi tersebut harus berlaku adil, meskipun menyangkut dirinya sendiri dan keluarganya atau pertimbangan sosial lainnya, Wahai orang-orang yang beriman, jadilah kamu orang yang benarbenar penegak keadilan, menjadi saksi karena Allah biarpun terhadap dirimu sendiri atau ibu bapa dan kaum kerabatmu. Jika ia kaya ataupun miskin, maka A llah lebih tahu kemaslahatannya (an-Nisa': 135). Dan bahkan dalam kasus rujuk dan perceraianpun saksi harus orang yang adil, A pabila mereka telah mendekati akhir iddahnya, maka rujukilah mereka dengan baik atau lepaskanlah mereka dengan baik dan persaksikanlah dengan dua orang saksi yang adil di antara kamu dan hendaklah kamu tegakkan kesaksian itu karena A llah (at-Thalaq: 2). Bahkan karena yang terpenting dari kesaksian adalah kompetensi, dalam wasiat diperbolehkan kesaksian non muslim, Hai orang-orang yang beriman, apabila salah seorang kamu menghadapi kematian, sedang dia akan berwasiat, maka hendaklah (wasiat itu) disaksikan oleh dua orang yang adil di antara kamu, atau dua orang yang berlainan agama dengan kamu, (al-Maidah: 106).

Begitu pentingnya keadilan dalam kesaksian, sehingga dalam transaksi muamalah Allah SWT melarang seseorang yang memiliki kompetensi Ialu ia enggan memberikan kesaksiannya, begitu pula orang yang memiliki kompetensi untuk melakukan pencatatan namun ia bosan mencatatnya, Janganlah saksi-saksi itu enggan (memberi keterangan) apabila mereka dipanggil; dan janganlah kamu jemu menulis hutang itu, baik kecil maupun besar sampai batas waktu membayarnya. (al-Baqarah: 282) Demikian pula halnya Allah SWT melarang seorang saksi yang mengikuti hawa nafsunya, lalu ia menyimpang dari 
kebenaran dengan memutarbalikkan fakta yang ada, Maka janganlah kamu mengikuti hawa nafsu karena ingin menyimpang dari kebenaran. Dan jika kamu memutar balikkan (kata-kata) atau enggan menjadi saksi, maka sesungguhnya A llah adalah $\mathrm{M}$ aha $\mathrm{M}$ engetahui segala apa yang kamu kerjaan. (an-Nisa': 135), Allah juga menyebutkan penulis dan saksi yang mempersulit urusan sebagai orang fasik, dan janganlah penulis dan saksi saling sulit-menyulitkan. Jika kamu lakukan (yang demikian), maka sesungguhnya hal itu adalah suatu kefasikan pada dirimu. (alBaqarah: 282) dan bahkan disebut sebagai orang yang berdosa, dan janganlah kamu (para saksi) menyembunyikan persaksian. Dan barangsiapa yang menyembunyikannya, maka sesungguhnya ia adalah orang yang berdosa hatinya; dan Allah M aha M engetahui apa yang kamu kerjakan. (al-Baqarah: 283).

Berdasarkan penjel asan ayat-ayat di atas dapat diketahui beberapa unsur berkaitan dengan kesaksian yang menjadikan kesaksian tersebut diterima atau ditolak:
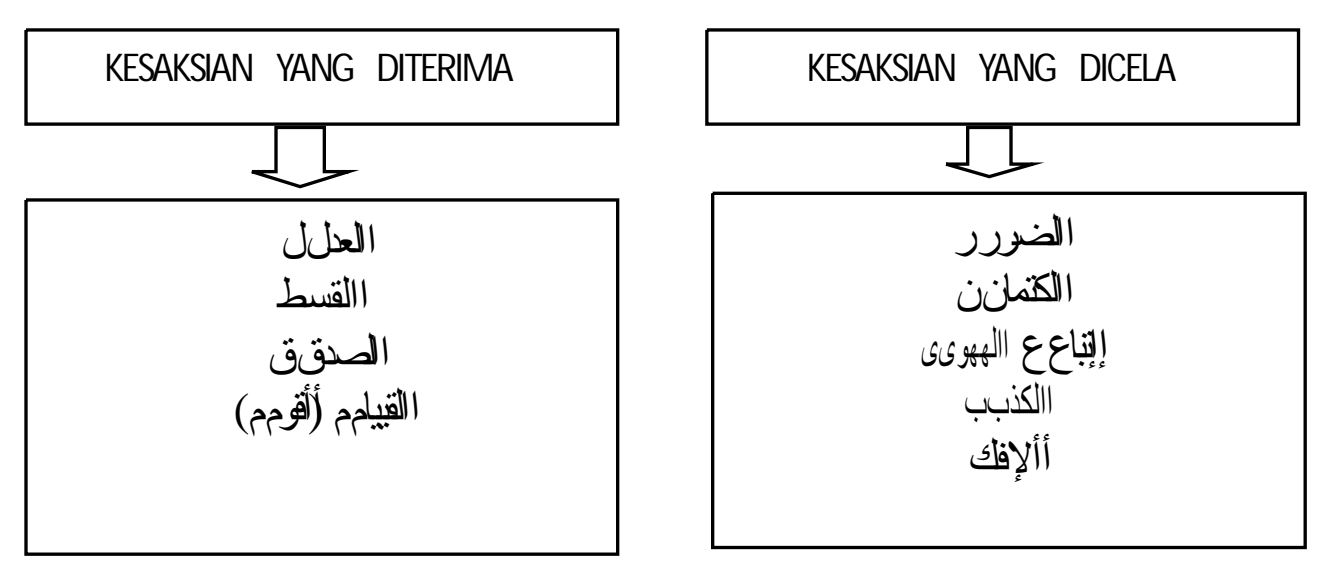

Untuk melihat lebih jauh kesaksian perempuan dalam transaksi muamalah dalam al Quran, perlu dihubungkan dengan kesaksian pada kasuskasus lain (berdasarkan kronologis turunnya) yang di dalam al Quran diharuskan adanya saksi.

Dalam kasus penyerahan harta kepada anak yatim oleh walinya diperlukan saksi, namun al Quran tidak menyebutkan jumlah saksinya dan juga apakah saksinya laki-laki atau perempuan:

(\#qäón=t/ \#s Î) \#ÓLym 4 yJ»tGu ø9\$\# (\#qè=tGö/\$\#ur

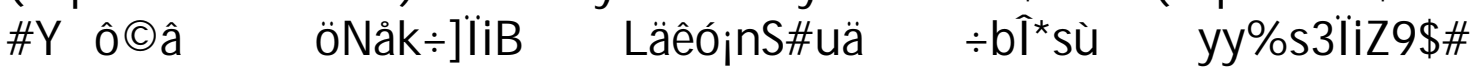

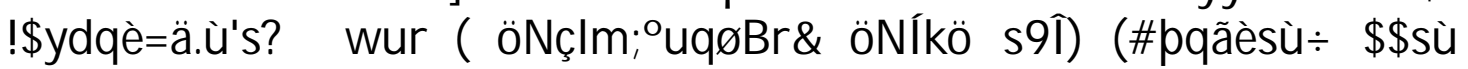
\$| ÏYxî tb\%x. 'tBur 4 (\#rç y9õ3t br\& \#. \#y $\hat{\mathrm{I}} /$ ur \$]ù\#u ó $\hat{\mathrm{I}}$ ) 
ö@ä.ù'u ù=sù \#Z É)sù tb\%x. ‘tBur ( ô\#İ̈ॅètGóju ù=sù

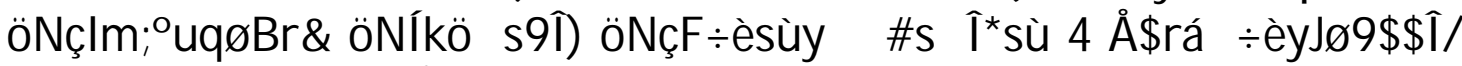
ÇİE \$Y7 Åiym «!\$\$1/ 4 xÿx.ur 4 öNÍkö n=tæ (\#rß Îkô---r'sù

Artinya: D an ujilah anak yatim itu sampai mereka cukup umur untuk kawin. Kemudian jika menurut pendapatmu mereka telah cerdas (pandai memelihara harta), maka serahkanlah kepada mereka harta-hartanya. D an janganlah kamu makan harta anak yatim lebih dari batas kepatutan dan (janganlah kamu) tergesa-gesa (membelanjakannya) sebelum mereka dewasa. Barangsiapa (di antara pemelihara itu) mampu, maka hendaklah ia menahan diri (dari memakan harta anak yatim itu) dan barangsiapa miskin, maka bolehlah ia makan harta itu menurut yang patut. Kemudian apabila kamu menyerahkan harta kepada mereka, maka hendaklah kamu adakan saksi-saksi (tentang penyerahan itu) bagi mereka. D an cukuplah A llah sebagai Pengawas (atas persaksian itu. (an-Nisa':

6)

Pada kasus rujuk atau perceraian terhadap isteri yang sudah habis masa iddahnya diperlukan dua orang saksi, namun dalam ayat ini juga tidak disebutkan apakah saksi tersebut dua orang laki-laki atau dua orang perempuan atau satu orang laki-laki bersama satu orang perempuan.

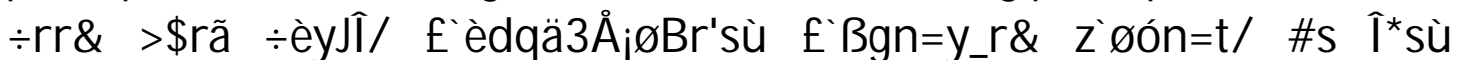

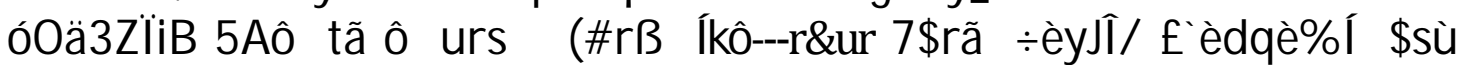

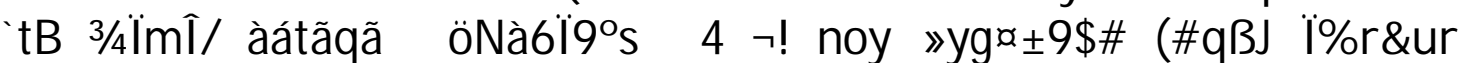

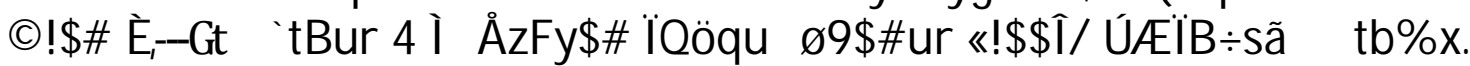

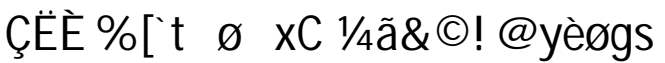

Artinya: A pabila mereka telah mendekati akhir iddahnya, maka rujukilah mereka dengan baik atau lepaskanlah mereka dengan baik dan persaksikanlah dengan dua orang saksi yang adil di antara kamu dan hen daklah kamu tegakkan kesaksian itu karena Allah. Demikianlah diberi pengajaran dengan itu orang yang beriman kepada Allah dan hari akhirat. Barangsiapa yang bertakwa kepada A llah niscaya Dia akan mengadakan baginya jal an keluar. (al-Thalaq: 2)

Dalam kasus wasiat, diperlukan dua orang saksi yang seagama (muslim) atau juga boleh dari yang non muslim.

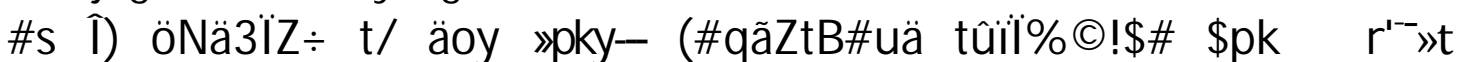
Ėb\$uZøO\$\# Ïp§ İ1 uqø9\$\# tûüÏm ßNöqyJø9\$\# ãNä.y tnr\& u |Øym $\div$ bî) öNä.Î ö xî ô ÏB Ėb\#t yz\#uä ־rr\& öNä3ZZ̈iB 5Aô tã \#urs

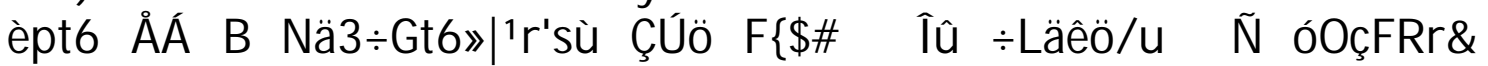

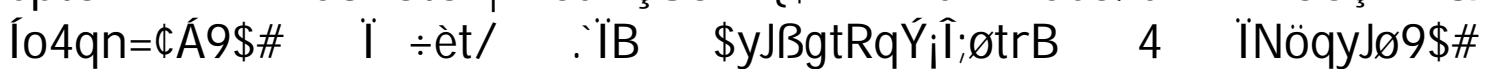

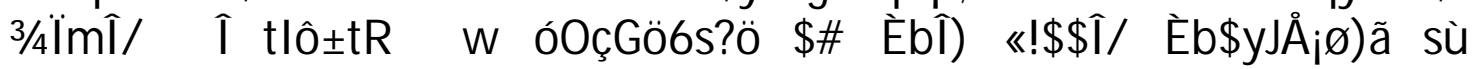


noy spky-- bOçFõ3tR wur 4 n1ö è\% \#s tb\%x. öqs9ur \$YYyJrO

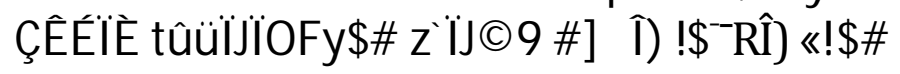

Artinya: Hai orang-orang yang beriman, apabila salah seorang kamu menghadapi kematian, sedang dia akan berwasiat, maka hendaklah (wasiat itu) disaksikan oleh dua orang yang adil di antara kamu, atau dua orang yang berlainan agama dengan kamu, jika kamu dalam perjalanan di muka bumi lalu kamu ditimpa bahaya kematian. Kamu tahan kedua saksi itu sesudah sembahyang (untuk bersumpah), lalu mereka keduanya bersumpah dengan nama Allah jika kamu ragu-ragu: "(D emi Allah) kami tidak akan menukar sumpah ini dengan harga yang sedikit (untuk kepentingan seseorang), walaupun dia karib kerabat, dan tidak (pula) kami menyembunyikan persaksian Allah; sesungguhnya kami kalau demikian tentulah termasuk orang-orang yang berdosa. (al-Maidah: 106)

Dalam kasus pembuktian perbuatan zina perlu empat orang saksi.

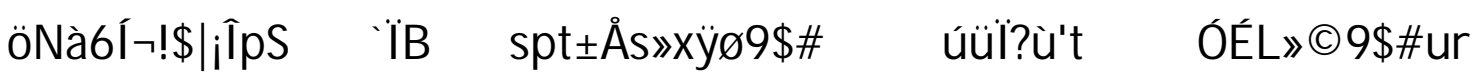

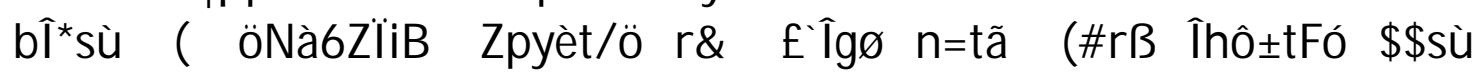
$4 O ́ \circledast L y m$ ÏNqqã ç6ø9\$\# Î̂

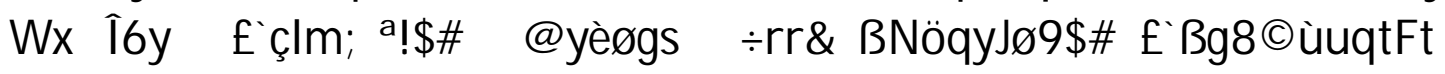

ÇÊİE

Artinya: Dan (terhadap) para wanita yang mengerjakan perbuatan keji, hendaklah ada empat orang saksi diantara kamu (yang menyaksikannya). Kemudian apabila mereka telah memberi persaksian, maka kurunglah mereka (wanita-wanita itu) dalam rumah sampai mereka menemui ajalnya, atau sampai Allah memberi jalan yang lain kepadanya. (an-Nisa': 15)

Ketika menerapkan hukuman kepada pelaku zina mesti disaksikan oleh orang banyak.

\$yJåk $\div$ ]ÏiB 7 Ïnôur “@ä. (\#rà\$Î\#ô_\$sù ÎT\#” 9\$\#ur èpu ÏR\#” 9\$\# Eûiï Î̂u xpsùù\&u \$yJíkí5 /ä.õ è\{ù's? wur ( ;ot\$ù\#y_sps (\$ÏB

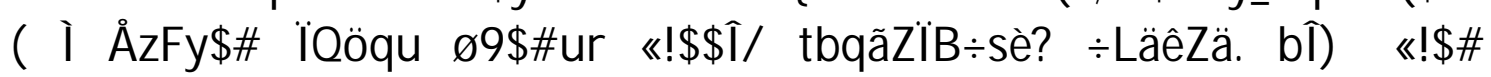

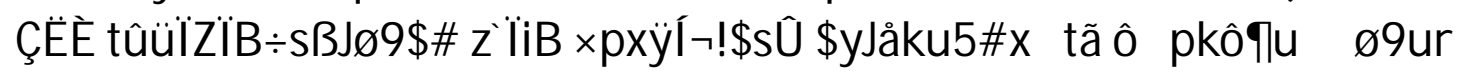

Artinya: Perempuan yang berzina dan laki-laki yang berzina, maka deralah tiap-tiap seorang dari keduanya seratus kali dera, dan janganlah belas kasihan kepada keduanya mencegah kamu untuk (menjalankan) agama Allah, jika kamu beriman kepada Allah, dan hari akhirat, dan hendaklah (pelaksanaan) hukuman 
mereka disaksikan oleh sekumpulan dari orang-orang yang beriman. (an-Nur: 2)

Pada kasus qadzaf diperlukan empat orang saksi.

(\#qè?ù't óOs9 §NèO ÏM»oY|ÁósßJø9\$\# tbqãBö t tûï̈\%@!\$\#ur Zot\$ù\#y_tûüÏZ»uKrO óOèdrß $\hat{\mathrm{I}}=0 \hat{\text { _ }} \$$ \$sù uä!\#y pkà- Ïpyèt/ö r'î/

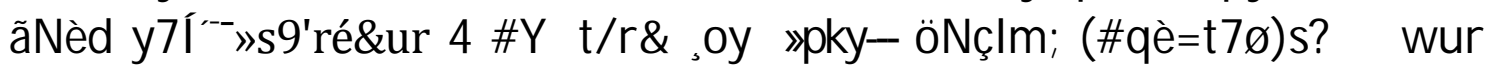

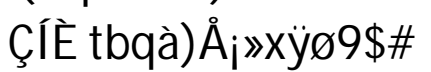

Atinya: Dan orang-orang yang menuduh wanita-wanita yang baik-baik (berbuat zina) dan mereka tidak mendatangkan empat orang saksi, maka deralah mereka (yang menuduh itu) delapan puluh kali dera, dan janganlah kamu terima kesaksian mereka buat selama-lamanya. D an mereka itulah orang-orang yang fasik. (an-Nur: 4)

Dalam beberapa ayat yang disebutkan terakhir ini dengan menggunakan perintah tentang perlunya kesaksian, namun tidak dirinci seperti ketika al Quran berbicara tentang transaksi muamalah, bahkan pada kasus wasiat diperbolehkan kesaksian non muslim.

\section{SIM PULAN}

Kata syahida memiliki dua makna yaitu, kesaksian langsung dan kesaksian tidak langsing. Ulama berbeda tentang kesaksian perempuan dalam bidang muamalah. Perbedaan tersebut disebabkan berbeda dalam melihat illat hukum, apakah teks atau konteks, apakah syar'iy atau 'urfiy.

\section{Endnotes:}

1 Penelusuran kata syahida tersebut dengan menggunakan program H oly Q ur'an 6.5 Plus.

2 Kategori tentang makiyah dan madaniyah tentunya terdapat bahasan yang panjang dengan berbagai varian pendapat yang ada, namun yang dimaksud dalam tulisan ini adalah berdasarkan teori yang menyebutkan bahwa makiyah adalah ayat-ayat yang diturunkan sebelum nabi Muhammad saw hijrah ke Yasrib, baik yang diturunkan di Makkah maupun di tempat lain. Sedangkan madaniyah adalah ayat-ayat yang diturunkan setelah nabi hijrah ke Yasrib, baik diturunkan di Madinah atau lainnya. Penjelasan lebih lanjut dapat dilihat dalam Imam Jalaluddin Abdurrahman ibn Abu Bakar al-Suyuthy al-Syafii (selanjutnya ditulis Suyuti). 2000. Al-Itqan fi U lum al Q uran. Beirut: Daar al-Kutub al-IImiah. jilid 1, hlm. 19

3 Urutan kronologis surat dalam al Quran berdasarkan riwayat Ibn A bbas ini dapat dilihat pada Al-Imam Badruddin Muhammad ibn Abdillah al-Zarkasyi (selanjutnya ditulis Zarkasyi). 1988. Al-Burhan fi U lum al Q uran. Beirut: Daar al-Fikr. jilid 1, hlm. 249-251. Dapat juga dilihat pada Muhammad Salim Mahisan. $1401 \mathrm{H}$. Tarikh al Quran al-Karim. Iskandariyah: Muassasah Syabab al-Jami'ah. hlm. 50-53. Lihat juga A bu A bdillah al-Zanjani (alih bahasa oleh Kamaluddin Marzuki Anwar dan A. Qurtubi Hasan). 1986. W awasan Baru Tarikh al Q uran. Bandung: Mizan. hlm. 77-79 
4 Lihat 'Allamah A bi al-Fadhl Jamal al-Din Muhammad ibn Mukram ibn Manzhur al-A friqiy al-Mishriy (lebih lanjut ditulis Ibn Manzhur). 1990. Lisan al-'A rab. Beirut: Daar al-Fikr. jilid 3, hlm. 239, lihat juga Mujid al-Din Muhammad ibn Ya'kub al-Fairuzzabadiy. t. th. AlQ amus al-M uhith. Beirut: Daar al-Jail. jilid 1, hlm. 316 dan bandingkan juga dengan Luis Ma'luf. 1986. Al-M unjid fi al-Lughah wa al-A'lam. Beirut: Daar al-Masyriq. cet. Ke 38. hlm. 406.

5 Ibn Manzhur, Ibid.

6 Imam Fakruddin al-Razi (selanjutnya ditulis Razi), A I-T afsir al-Kabir (M afatih al-Ghaib), jilid 4, juz 7, hlm. 96

7 Ibid.

8 Abu al-Fida' Ismail ibn Umar ibn Katsir al-Qarsyiy al-Dimasyqiy (selanjutnya ditulis Ibn Katsir). t. th. Tafsir al Quran al-'Azhim. Kairo: Maktabah Mishr. jilid 1, hlm. 335

9 Abu Ja'far Muhammad ibn Jarir al-Thabariy (selanjutnya ditulis Thabari). 1988. Jami' alBayan 'an Takwil A yy al Quran. Beirut: Daar al-Fikr. jilid 2, juz 3, hlm. 125

10 Razi, Al-Tafsir al-Kabir, hlm. 96

11 Ibid., hlm. 96

12 Sayyid Quthub. 1971. Fi Z hilal al Q uran. Beirut: Daar al-Ihya' al-Turats al-'Arabiy. jilid 1, juz 3, hlm. 493

13 Al-Imam Hujjat al-Islam Abu Bakar Ahmad ibn Ali al-Raziy al-Jashshash (selanjutnya ditulis Jassas). t.th. A hkam al Q uran. Beirut: Daar al-Kutub al-IImiah. jilid 1, hlm. 608

14 Al-Imam Abu Abdullah Muhammad ibn A hmad al-Anshariy al-Qurthubiy (selanjutnya ditulis Qurtubi). 1993. Al-Jami' li A hkam al Q uran. Beirut: Daar al-Kutub al-Ilmiah. jilid 3, hlm. 252

15 Lihat A bu Bakar Muhammad ibn Abdullah ibn Arabi (selanjutnya ditulis Ibn Arabi). 1988. A hkam al Q uran. Beirut: Daar al-Fikr. jilid 1, hlm. 335

16 Imam Muhammad Rasyid Ridha. 2007. Tafsir al Quran al-Hakim (Tafsir Al-M anar), Beirut: Daar al-Fikr. jilid 1, hlm. 790

17 Ibid., hlm. 791

18 A bdul Karim al-Khatib. t. th. A I-Tafsir al Qurani li al Q uran. Cairo: Daar al-Fikr al-Arabi. jilid 2, juz 3, hlm. 381

19 Wahbah al-Zuhailiy. 1998. Tafsir al-M unir fi al-'A gidah wa al-Syari'ah wa al-M anhaj. Beirut: Daar al-Fikr. Jilid 2, juz 3, hlm. 110-111

20 Abu Su'ud Muhammad ibn Muhammad ibn Musthafa al-'Imadi al-Hanafi (selanjutnya ditulis A bu Su'ud). 2001. Irsyad al-'A ql al-Salim Ila Mizaya al-Kitab al-Karim Tafsir A bi alSu'ud. Beirut: Daar al-Fikr. jilid 1, hlm. 472. Lihat juga Jassas, loc.cit.

21 Abu Muhammad al-Husain ibn Mas'ud al-Farra' al-Baghawi (selanjutnya disebut Baghawi). 1985. M a'alim al-Tanzil fi al-Tafsir wa al-Takwil. Beirut: Daar al-Fikr. jilid 1. hlm. 409

22 Ibid.

23 Jassas, hlm. 608

24 Al Quran menjelaskan bahwa Kami tidan menurunkan al Quran ini kepadamu agar kamu menjadi susah (Thaha: 2), tetapi tujuan al Quran itu diturunkan sebagai petunjuk bagi manusia, penjelasan-penjelasan mengenai petunjuk itu dan pembeda [antara yang hak dan yang batil] (al-Baqarah: 185) selanjutnya juga berpungsi untuk memberi petunjuk ke jalan yang lebih lurus (al-Isra': 9) dalam wujud penawar dan rahmat bagi orang mukmin (alIsra': 82) serta petunjuk bagi orang yang bertaqwa (al-Baqarah: 2).

25 Lihat Wahbah al-Zuhaili. 1992. U shul al-Figh al-Islamiy. Beirut: Daar al-Fikr. jilid 1. hlm. 646 
$26 \quad$ Ibid., hlm. 624 dan 651

27 Menurut Ibn Arabi kesaksian perempuan setengah kesaksian laki-laki karena enam hal, yaitu: Laki-laki adalah asal sedangkan perempuan adalah cabang; Perempuan diciptakan dari tulang rusuk yang bengkok; Kurang agamanya; Lemah akalnya; Bahagiannya dalam warisan kurang; Kurang tenaganya.

28 Al-Imam al-Akbar Mahmud Syaltut. 1966. Al-Islam 'A gidah wa Syari'ah. Kairo: Daar alQalam. hlm. 248-249.

\section{DAFTAR PUSTAKA}

Abu Su'ud Muhammad ibn Muhammad ibn Musthafa al-'Imadi al-Hanafi. 2001. Irsyad al-'A ql al-Salim Ila M izaya al-Kitab al-Karim Tafsir A bi alSu'ud. Beirut: Daar al-Fikr

Baghawi, Abu Muhammad al-Husain ibn Mas'ud al-Farra' al-Baghawi. 1985. M a'alim al-Tanzil fi al-Tafsir wa al-Takwil. Beirut: Daar al-Fikr

Fairuzzabadiy, Mujid al-Din Muhammad ibn Ya'kub. t.th. A I-Q amus al-M uhith. Beirut: Daar al-Jail

Ibn Arabi, Abu Bakar Muhammad ibn Abdullah ibn Arabi. 1988. Ahkam al Quran. Beirut: Daar al-Fikr

Ibn Katsir, Abu al-Fida' Ismail ibn Umar, Tafsir al Quran al-'Azhim, (Kairo: Maktabah Mishr, t.th.).

Ibn Manzhur, 'Allamah Abi al-Fadhl Jamal al-Din Muhammad ibn Mukram. 1990. Lisan al-'A rab. Beirut: Daar al-Fikr

Jassas, Al-Imam Hujjat al-Islam Abu Bakar Ahmad ibn Ali al-Raziy alJashshash. t.th. A hkam al Q uran. Beirut: Daar al-Kutub al-IImiah

Khatib, Abdul Karim, Al-Tafsir al Qurani li al Quran. t.th. Cairo: Daar al-Fikr alArabi

Ma'luf, Luis. 1986. Al-M unjid fi al-Lughah wa al-A 'lam. Beirut: Daar al-Masyriq

Mahisan, Muhammad Salim. 1401 H. Tarikh al Quran al-Karim. Iskandariyah: Muassasah Syabab al-Jami'ah

Qurtubi, Al-Imam Abu Abdullah Muhammad ibn Ahmad al-Anshariy alQurthubiy. 1993. Al-Jami' li A hkam al Quran. Beirut: Daar al-Kutub alIImiah

Quthub, Sayyid. 1971. Fi Zhilal al Quran. Beirut: Daar al-Ihya' al-Turats al'A rabiy 
Razi, Imam Fakruddin. t.th. A I-Tafsir al-Kabir (M afatih al-Ghaib), jilid 4, juz 7. t. penerbit

Ridha, Imam Muhammad Rasyid. 2007. T afsir al Q uran al-H akim Tafsir A I-M anar. Beirut: Daar al-Fikr

Suyuthy, Imam Jalaluddin A bdurrahman ibn Abu Bakar. 2000. A I-Itqan fi U lum al Quran. Beirut: Daar al-Kutub al-IImiah

Syaltut, AI-Imam al-Akbar Mahmud. 1966. A I-Islam 'A qidah wa Syari'ah. Kairo: Daar al-Qalam

Thabariy, A bu Ja'far Muhammad ibn Jarir. 1988. Jami' al-Bayan 'an Takwil Ayy al Quran. Beirut: Daar al-Fikr

Zanjani, A bu Abdillah, (alih bahasa oleh Kamaluddin Marzuki Anwar dan A. Qurtubi Hasan). 1986. Wawasan Baru Tarikh al Quran. Bandung: Mizan

Zarkasyi, Al-Imam Badruddin Muhammad ibn Abdillah. 1988. Al-Burhan fi Ulum al Quran. Beirut: Daar al-Fikr

Zuhailiy, Wahbah. 1998. Tafsir al-M unir fi al-'A gidah wa al-Syari'ah wa al-M anhaj. Beirut: Daar al-Fikr

Zuhailiy, Wahbah. 1992. U shul al-Figh al-Islamiy. Beirut: Daar al-Fikr 